\title{
On the Case for Graduation
}

\author{
by K. A. Koekkoek, Rotterdam*
}

The goal of phasing out, and ultimately eliminating, the differential treatment in trade presently accorded to developing countries was incorporated into the GATT during the Tokyo Round. What are the arguments in favour of this process of "graduation" and what would be its disadvantages? Which criteria should be applied to the selection of countries for graduation?

$\mathrm{O}^{\mathrm{n}}$ ne of the most important results of the Tokyo Round of multilateral trade negotiations for developing countries was the introduction of the Enabling Clause. The Enabling Clause resulted as part of the negotiations in the so-called Framework Group, which had the explicit task of considering "improvements in the international framework for the conduct of world trade which might be desirable in the light of progress in the negotiations". ${ }^{1}$ The Enabling Clause represents a trade-off between developing countries' wishes to institutionalize preferential treatment for their exports, on the one hand, and the industrial countries' wish for developing countries to participate in international trade on an equal basis with them, on the other. Therefore this clause provides the legal framework for preferential treatment of developing countries' exports both to industrialized countries and among themselves. As the price to be paid for this, the Enabling Clause also "states the expectation of developing countries that they will be able to participate more fully in the framework of rights and obligations under the GATT with the progressive development of their economies and improvement of their trade situation". ${ }^{2}$

One of the reasons that not many developing countries have signed the Tokyo Round Agreements as yet is their dissatisfaction with this latter part of the Enabling Clause. Although the wording is rather vague and there is no time element involved, it is clearly to be understood as a first step towards abolishing preferential treatment at some time in the future. This future proved to be even nearer than the developing countries may have perceived at the time, for in the preparations for the GATT ministerial meeting in the

*Erasmus Universiteit. autumn of 1982 several developed countries stated, sometimes in a rather forceful way, that the graduation of developing countries should be a major topic on the agenda. "Graduation" means that the preferential treatment of developing countries in their international trade relations is to be progressively phased out. Graduation in the context of GATT is only one aspect of graduation in general which, it must be emphasized, is not a new phenomenon. It has always been with us, in various forms. The following examples may clarify this. ${ }^{3}$

\section{Graduation in Practice}

In so far as access to lending facilities of the World Bank is determined by the per capita income of the prospective borrowing country, there is a clear case of graduation. With regard to the IMF, there are member countries subject to article VIII and member countries subject to article XIV. The main difference between these two groups of countries is that those subject to article XIV may engage in discriminatory currency practices, while article VIII countries need the IMF's permission to do that. Graduation from article XIV to article VIII status is solely the responsibility of the country concerned.

A third example may be found in the working of the Stabex facility of the EC. Stabex is a part of the Lomé Convention. It is meant to stabilize the export earnings of the developing countries associated with the EC. To that effect, these countries get loans when commodity

1 GATT: The Tokyo Round of Multilateral Trade Negotiations, Geneva, April 1979, p. 9.

2 GATT, op. cit., p. 149.

${ }^{3}$ For an extensive treatment, see I. F r a n k: The "Graduation" Issue for LDCs, in: Journal of World Trade Law, Vol. 13, No. 4, 1979, pp. 289302. 
export proceeds are below a certain trend value. These loans have to be paid back upon an advantageous price and volume development of these exports. Graduation comes into this scheme because the least developed among the associated countries have easier access to the compensation and are not required to pay back anything.

Finally, within existing generalized systems of preferences another type of graduation exists, which may be called productwise graduation. This means that when a developing country is successful enough in exporting a certain product, that product does not qualify for preferential treatment any more. In the case of the EC preferential scheme, success is measured according to the fulfilment of the preferential quota, beyond which treatment is reinstated. In the case of the US scheme, a developing country will lose its preferential treatment for the next year for any product for which it accounts for more than $50 \%$ of total US imports of that product, or for any product, imports of which into the United States exceed a specified dollar ceiling (\$ 25 million in 1974 and annually adjusted to reflect the growth of US GNP).

It is thus clear that several types of graduation do exist, albeit mostly outside the field of trade relations. Any discussion about graduation within this field should thus be concerned not so much with the principle, for which a good case exists logically and historically. More interesting are the reasons behind the surfacing of the matter right now, the particulars of application to the field of trade relations and the criteria to be used in implementing this type of graduation.

\section{Why Graduation in Trade Relations?}

Let us first establish what graduation in the field of trade relations would imply. At its most extreme, it would amount to complete equalization of rights and duties, with regard to trade policy measures, between rich and graduating poor countries. This would involve not only abolishment of preferential systems for those LDCs, but also full application of the various codes of conduct agreed upon in the Tokyo Round. These codes of conduct deal, among other things, with export subsidies, customs valuation, government procurement and technical barriers to trade. Furthermore, these countries would have to adhere to the principle of reciprocity, i.e. they would have to open up their markets in exchange for easier access to other economies' markets.

There is probably one main reason for the timing of the present demands for graduation, namely the slowdown of the rich countries' economies. This slowdown, and accompanying aspects such as low competitiveness, employment losses and so on, are often at least partly ascribed to the success of a number of developing countries in the sphere of industrial

\title{
PUBLICATIONS OF THE HWWA-INSTITUT FÜR WIRTSCHAFTSFORSCHUNG-HAMBURG
}

\section{New Publication}

\section{Walter Bakenecker}

\section{PORTFOLIOTHEORETISCHE WECHSELKURSANALYSE (PORTFOLIO-THEORETICAL EXCHANGE RATE ANALYSIS)}

\begin{abstract}
The present study offers a contribution towards the integration of flow- and stockoriented approaches in exchange rate theory. The author combines a financial market approach oriented towards stock variables with a model of internal and external equilibrium which is based on the theory of flow variables. The analysis of the interactions between the real and the financial spheres of a national economy makes it possible to determine, besides other macro-economic variables, the exchange rate. (In German.)
\end{abstract}

Large octavo, 260 pages, 1983, price paperbound DM 49,-

ISBN 3-87895-235-X
V E R L A G
W E L T A R C H I V
G M B H
H A M B U R G 
exports. ${ }^{4}$ This success is partly reflected in the performance of the developing countries in the preferential systems. More generally, the phenomenon of the newly industrializing countries shows that at least a number of developing countries enjoyed a very good industrial export performance in the seventies.

\section{The Role of Preferential Systems}

Generalised systems of preferences have been established because of the dissatisfaction of the LDCs with the working of the GATT system. Very generally, their reasoning can be described in the following way. LDCs could not really profit from the GATT system because they were not capable of offering tariff concessions and so they did not get any concessions in return. They also did not benefit from the tariff decreases offered by rich countries amongst themselves as these countries mostly traded concessions of typical DC-products. As one cannot profit from a tariff concession if one does not export the product concerned, the LDCs thus did not benefit from the mfn clause either.

So already at UNCTAD I, in 1964, the LDCs insisted upon preferential treatment for their exports, later typified by the slogan "unequal treatment for unequal partners". The purpose of preferential treatment was to promote industrial exports, economic growth and development of LDCs in general. This promotion was to take place via positive discrimination of LDCs' industrial exports, i.e. preferential access to industrial countries' markets. Tariff concessions were to be granted to the LDCs, while the mfn clause would not apply and no reciprocity from their part was expected. The original idea was to have one generalized system of preferences of all developed countries for all developing countries. It did not come about that way. On the contrary, a number of preferential systems were initiated by individual DCs or groups of DCs, such as the $E C$, during the first half of the seventies. Although these systems had the same purpose their workings differed in many details, which we need not go into here. ${ }^{5}$ Suffice

\footnotetext{
${ }^{4}$ This is not the place to judge whether this is a correct position. The developing countries probably contribute in only a minor way to the present problems of the rich countries.

${ }^{5}$ For a precise description, see e.g. T. M u r r a y : Trade Preferences for Developing Countries, London 1977; A. We s t o n, V. C a b le, A. Hew itt: The EEC's Generalised System of Preferences, ODI, 1980; or A. Borrmann, C. Borrman n, M. Stegger: Das Allgemeine Zollpräferenzsystem der EG, Hamburg 1979.

6 See e.g. T. Murray: How Helpful is the Generalized System of Preferences to Developing Countries?, in: Economic Journal, Vol. 83, 1973, pp. 449-455.

7 UNCTAD TD/B/C.5/66, 20 February 1980 (prepared by T. Murray): Evaluation of the Trade Benefits under the United States Scheme of Generalized Preferences.
}

it to say that the original idea was somewhat watered down via the introduction of a great number of restrictions, e.g. tariff quotas, rules of origin, competitive need criteria, and so on. As a consequence many observers did not have great expectations of the preferences. ${ }^{6}$

Because of this initial pessimism it is of some interest to quote the results of research by several authors into the effectiveness of the preferential systems. First, there is a study by UNCTAD on the effectiveness of the US scheme of preferences. ${ }^{7}$ This study tries to determine the main factors contributing to the growth of US imports from countries benefitting from its preferential scheme. One of the main results is that between 1974 and 1977 some $65 \%$ of the real growth in imports from the beneficiary countries can be attributed to the working of the US preferential scheme. Secondly, there is a study by Sapir concerning the effect of the EC system of preferences. ${ }^{8}$ Sapir tries to determine, in a gravity type of trade model, whether there are any significant effects from the preferential system upon trade flows. He does find a significantly positive effect, especially for goods in SITC groups 7 and 8 . In his words, "It does appear that the EEC GSP has expanded manufacturing exports from semi-industrialized nations in the few years after its inception". ${ }^{9}$ Thirdly, there is another study on the EC preferential system which states, "There is thus clear evidence of the stimulatory effect of the GSP on trade". ${ }^{10}$ This conclusion is drawn despite many criticisms by the authors with respect to the working of the system.

Finally the results of a study by Baldwin and Murray are interesting. ${ }^{11}$ They compared the benefits of tariff reductions under the mfn clause with the GSP benefits, via the calculation of the amounts of trade creation and diversion following both types of concessions. They concluded that the LDCs, as a whole, stood to gain more from $\mathrm{mfn}$ tariff concessions than from the GSP schemes, in particular because of the many restrictions on the GSP schemes. This conclusion applied of course mainly to those countries being restricted by the rules of the GSP. Summarizing, one might say that in general developing countries benefit from preferential systems, but that these benefits are restricted because of the

${ }^{8}$ A. S a pi r : Trade Benefits under the EEC Generalized System of Preferences, in: European Economic Review, Vol. 25, 1981, pp. 339355.

${ }^{9}$ A. Sa pir, op. cit., p. 352.

${ }^{10}$ A. Borrmann, C. Borrmann, M. Stegger: The Impact of the GSP on Imports, in: INTERECONOMICS, No. 5, 1979, $p$. 224.

11 R. E. B aldwin, T. Murray: MFN Tariff Reduction and Developing Country Trade Benefits under the GSP, in: The Economic Journal, Vol. 87, March 1977, pp. 33-46. 
many limitations of these systems. Thus preferential systems have, at least to some extent, served their purpose. Insofar as that is true, of course, it serves at the same time as a valid reason for the call for graduation.

\section{Newly Industrializing Countries}

Another, and more general, clear indication of the LDCs' success in exporting industrial products is the increasing concern with the newly industrializing countries (NICs). It is hard to give a precise definition of NICs. In the literature one may find some five, partly overlapping, groups of NICs distinguished. One may even doubt whether it is very useful to try to identify a certain group of countries as NICs. Anyway, the general idea is that NICs are developing countries that have very quickly become successful exporters of industrial products. As such, many more developing countries than the ten or so usually considered have certain NIC aspects. ${ }^{12}$

This is not the place to go into a detailed explanation of the reasons behind the success of the NICs. ${ }^{13}$ It will suffice here to give a brief summary of the factors to which the NICs' success is generally attributed.

These are a combination of outward-looking growth policies and a number of individual factors. According to the product cycle theory, a dynamic theory of international trade, new products, involving much $R$ \& $D$ spending and highly skilled labour, are originally produced in the rich countries and exported to the poor. Later on, as the production process becomes standardized, R \& D inputs and skilled labour inputs become less important and unskilled labour becomes more important. The availability of large amounts of cheap unskilled labour in developing countries therefore means that the comparative advantage in producing those formerly new products then shifts from the rich to the poor countries. This can apply not only to complete products, but also to parts of the production process. This shift in comparative advantage is facilitated by the involvement of multinationals, due to their knowledge of production conditions and international markets and their flexibility. Another factor in this process is the existence of offshore assembly provisions: when a product is exported, further processed, and re-imported, import duties are only applied to that part of the value of the product that has been created abroad and not to the

\footnotetext{
12 This is partly recognized in a recent OECD study: Development Cooperation, 1982 Review, OECD, Paris 1982, Ch. 12, dealing with "new" NICs.

13 See for a general discussion e.g. OECD, op. cit., or an older study by the OECD: The impact of the Newly Industrializing Countries on Production and Trade in Manufactures, OECD, Paris 1979.
}

total value of the imported product. This, of course, increases the attractiveness of processing abroad. Besides these general factors there are, of course, individual factors which also help to explain individual countries' performance, e.g. political factors, size of the home market, level of education of the labour force, etc.

The conclusion from both the experience with the preferential schemes and the performance of the NICs is the following. A number of developing countries have shown their ability to compete in world markets, both with and without preferences. From that point of view it is both reasonable and advantageous that they accept the implementation of the principle of graduation. It still remains to be seen, of course, whether there are other considerations which weigh in favour of, or against, the implementation of graduation. If, after considering the pros and cons, graduation would still seem advantageous, necessary or even unavoidable, there remains the crucial problem of the form of graduation and the criteria to be applied in deciding whether certain countries (or products) would qualify.

\section{The Price to Be Paid}

There are several other arguments in favour of graduation. Firstly, as graduating poor countries would diminish their own import barriers, rich as well as other poor countries would have more opportunity for exporting to these countries. On the basis of reciprocity this might induce rich countries to be less protectionist towards these same countries. On the other hand, it is of course doubtful whether other poor countries would really benefit in this way, as they would have to compete on an equal footing with the rich countries. Secondly, diminishing preferences for graduating countries in the rich countries' import markets would leave more room there for the poorer countries. But again they would have to compete for this extra room with the rich countries, albeit on the basis of preferences in this case. Thirdly, as graduation would help diminish distortions on both the import and export side of their economies, it would increase the welfare of these countries. In this case all the arguments of the export promotion versus import substitution debate do apply.

The most general and compelling argument against graduation is of course related to the balance-ofpayments shortages most poor countries are suffering. The question is posed whether poor countries can really afford graduation, which would probably, at least in the short run, worsen their balance-of-payments position. However, in so far as these shortages are caused by shortages in the energy trade balance they should not in 
my opinion, be used as an argument against graduation as that problem will have to be solved mainly by appropriate energy demand and supply policies, difficult as that may be. ${ }^{14}$ Another argument states that poor countries are only competitive in a small number of products. While probably rich countries are competitive in a greater range of products than poor countries, this range is, almost by definition, of course limited too. In general then this is not a valid argument, although one might think of extreme cases here, e.g. jute products from Bangla Desh.

Altogether, to my mind, the arguments in favour of graduation do outweigh those against. The main disadvantage, a worsening balance-of-payments position, might be taken care of via the introduction of a temporary fund which would compensate countries for graduation-related balance-of-payments shortages. The specifics of this fund, although not unimportant, do not matter for the argument. Also, graduation would have to be country-wise, not product-wise, as is aiready implicitly stated above. And if a different weighting of the arguments above, or still other considerations, lead one to reject graduation, there still remains the political pressure from the rich countries to be taken into account, and graduation might then well be seen as the price to be paid to escape from, or at least diminish, protectionist measures from the rich countries against (some of) the poor countries. Either way one would need to have certain criteria according to which countries would be considered for application of graduation.

\section{Criteria for Competitiveness}

While in the end the process of choosing countries eligible for graduation may well be more of a political than of an economic nature, it is still worthwhile to consider some "objective" elements that might enter this process. The essence of graduation involves the increasing competitiveness of developing countries in international markets. Therefore any set of graduation criteria should include elements representing a country's (increase in) competitiveness, in particular in industrial products. In this connection, one may think of changes in market shares, either worldwide, or in particular regional markets. Another possibility concerns changes in the structure of industrial exports.

A second consideration might be the level of development, e.g. measured by per capita income. In my opinion this should work not so much by excluding from graduation countries below some income level, as

\footnotetext{
${ }^{14}$ Energy trade balance shortages are likely to become less anyway due to the recent price weakening of oil.
}

rather by making countries above that income level eligible, in principle, for graduation.

A third, aspect might be sought in the factors determining competitiveness, instead of in the results of increasing competitiveness, as e.g. represented by increasing market shares. In this case one might think of the level of education of the labour force.

Of course it is possible to think of still other, maybe more refined, criteria to be applied but that is likely to be a superfluous exercise, as graduation is probably going to be a matter of rough and ready criteria.

\section{An Inescapable Phenomenon}

It seems that graduation is an inescapable phenomenon, by definition in the long run, but also, for political and other reasons, probably in the short run. In that case it is more advantageous for developing countries to cooperate in finding a reasonable system of graduation, than to try to stem the tide. It may well be a matter of "graduate or be graduated". ${ }^{15}$

In co-operating with the rich countries in the establishment of graduation rules, the poor countries may find an opportunity to attenuate the main external disadvantage of graduation, i.e. increased balance-ofpayments problems, via e.g. a temporary fund as suggested above. Also, the rich countries may find this an opportunity to soften the blow of graduation by increasing preferences for the poorer developing countries. By doing so, they would show that their intention is not merely to decrease competition from the developing countries in general, but also to promote the interests of those developing countries that can clearly not yet compete in the international markets.

Finally, it might be possible then to agree upon a reasonable time schedule for the implementation of graduation for the countries considered eligible. One might even distinguish several phases of graduation. First could come abolishment of preferences. The following step could consist of a more rigid application of some of the codes of conduct, agreed upon in the Tokyo Round, in particular that dealing with subsidies. The final phase would then consist of full application of all the codes as they apply for the developed country members of GATT right now.

\footnotetext{
15 According to the "Economisch Dagblad", April 6th, 1983, p. 9 William Brock, US trade representative, has stated that goods worth 2.6 billion dollars have been taken out of the GSP of the US. This concerns in particular products coming from Taiwan, Mexico, Singapore, South Korea and Chile. On the other hand, goods worth 300 million dollars have been brought under the GSP. Among these products is sugar, US imports of which were worth 175 million dollars in 1982, benefitting Guatemala, Colombia, Argentina, the Philippines and Swaziland.
} 